\title{
London Ramadan Fasting Study (LORANS): Rationale, design, and methods
}

Rami Al-Jafar (https://orcid.org/0000-0002-9393-7585) MSc 1, Paul Elliott, PhD ${ }^{1,2,3}$,

Konstantinos K. Tsilidis, PhD ${ }^{1,4}$, Abbas Dehghan, $\mathrm{PhD}^{1,2,5}$

${ }^{1}$ Department of Epidemiology and Biostatistics, School of Public Health, Imperial College London, W2 1 PG, London, UK.

${ }^{2}$ Dementia Research Institute at Imperial College London, W2 1 PG, London, UK.

${ }^{3}$ National Institute for Health Research Imperial College Biomedical Research Centre, Imperial College London, W2 1 PG, London, UK

${ }^{4}$ Department of Hygiene and Epidemiology, University of Ioannina School of Medicine, 45110, Ioannina, Greece.

${ }^{5}$ MRC-PHE Centre for Environment and Health, School of Public Health, Imperial College London, W2 1 PG, London, United Kingdom.

Correspondence to:

Abbas Dehghan, Department of Epidemiology and Biostatistics, School of Public Health, Imperial College London, 1st floor, Norfolk Place, W2 1 PG, London, UK.

Email: a.dehghan@imperial.ac.uk

Rami Aljafar, Department of Epidemiology and Biostatistics, School of Public Health, Imperial College London, 1st floor, Norfolk Place, W2 1 PG, London, UK.

Email: r.al-jafar18@imperial.ac.uk

Word count of the main text: 2129 words (Excluding references, tables, or figures) Keywords: Ramadan fasting, lifestyle, blood pressure, food intake, anthropometric measurements, body composition, metabolic biomarkers. 


\section{Abstract}

Background - Hundreds of millions of Muslims fast during the month of Ramadan. The London Ramadan Fasting Study (LORANS) aims to assess the lifestyle changes during this month and investigate the effect of Ramadan fasting on health.

Methods - LORANS is an observational study of participants that follow religious fasting in Ramadan. We advertised, recruited, and visited participants in five mosques in London, United Kingdom. In total, 146 individuals were recruited before Ramadan in May 2019 of which 85 participated in the follow up visit after Ramadan. The study protocol was approved by the ethics committee affiliated to Imperial College London. A written informed consent was signed by all the participants. Every participant completed a questionnaire, a physical examination, and gave blood samples at each visit. Moreover, they completed a 3-day food diary before Ramadan and once again during Ramadan to record dietary changes during the month of fasting.

Results - The mean age of participants was $45.6 \pm 15.9$ years. $47.1 \%$ of the participants were females, $25.5 \%$ were obese, $4.7 \%$ were smokers, $14 \%$ were diabetic, $24 \%$ were hypertensive, and $5.2 \%$ had cardiovascular diseases. Data collection covered demographics, lifestyle, food intake, blood pressure, anthropometric measurements, body composition, and metabolic biomarker profiling.

Conclusion - By engaging with mosques, proper introduction of the study aims and convenient recruitment in the mosque, we were able to recruit a balanced population regarding age and sex and collected valuable data on Ramadan fasting using high-quality techniques. 
medRxiv preprint doi: https://doi.org/10.1101/2021.07.14.21260518; this version posted July 16, 2021. The copyright holder for this preprint (which was not certified by peer review) is the author/funder, who has granted medRxiv a license to display the preprint in perpetuity.

It is made available under a CC-BY 4.0 International license .

\section{Introduction}

Ramadan is the ninth month of the Islamic calendar. During Ramadan, Muslims fast from dawn until dusk. During this time, food and drinks are prohibited at least 11 hours a day for 28-30 days (1). Fasting is one of the five pillars of Islam that all Muslims must perform with few exceptions such as children, patients and travellers (2). Fasting brings in a major change in the lifestyle, including change in dietary intake, dietary diversity and dietary habits as well as drinking, smoking, physical activity, and even sleep patterns. Since over a billion Muslims might practice fasting every year, assessing its health effects is of clinical and public health importance.

Despite the widespread practice of Ramadan fasting, high-quality research is scarce on this area. Few studies have assessed the effect of Ramadan fasting on certain cardiometabolic risk factors, including weight, blood pressure, levels of serum glucose, lipids and nutritional intake. In most instances, the studies have reported contradicting conclusions. For instance, several researchers (3-11) reported a significant decrease in weight, BMI and waist circumference (WC) after fasting during Ramadan. No changes were noted on these parameters in some other studies (12-21). Blood pressure is another important risk factor for chronic diseases and has been reported to decrease following Ramadan fasting in some studies (22-26), but not to be influenced in some others $(12,27-30)$. Serum glucose was also reported to drop after Ramadan fasting in two studies $(4,31)$ and was higher in a separate study (8). Similarly, studies are not conclusive on how serum levels of HDL and LDL cholesterol are affected by Ramadan fasting. Some studies have shown a decrease in LDL and an increase in $\operatorname{HDL}(32)$, while others found opposite $(7,33)$ or no association (8).

The heterogeneity in the findings and lack of conclusiveness might be due to the limitations of these studies. Most of these studies are very small (sample sizes even less than 25), have 
medRxiv preprint doi: https://doi.org/10.1101/2021.07.14.21260518; this version posted July 16, 2021. The copyright holder for this preprint

recruited participants from only one ethnic group, and applied convenience sampling that does not represent the whole population (e.g. students). Such limitations may affect the validity of the results and hamper their generalizability $(34,35)$.

Moreover, the effects of Ramadan fasting might be variable in reality due to the wide range of variations in traditions attached to fasting, differences in cultures and various environmental factors. Altitude, for instance, is an essential factor that determines the duration of fasting. The exact number of hours that people should fast during Ramadan varies based on the altitude of the place but is generally between 11 to 18 hours (36). Moreover, working hours are reduced during Ramadan in some Islamic countries such as UAE, Saudi Arabia, Egypt, and Malaysia (37), while it stays the same in many other countries. Finally, socioeconomic status, level of physical activity, smoking, and alcohol consumption might modify the effect of Ramadan fasting (38).

Altogether, there is a need for large scale high-quality research that covers different age groups and various ethnicities to highlight the health effects of fasting in Ramadan on health. London is a multi-ethnic metropolitan city where approximately 1 million Muslims live. This allows a comprehensive study on Ramadan fasting including various ethnicities and cultures. Therefore, we conducted the London Ramadan Fasting Study (LORANS) to investigate the effect of Ramadan fasting on blood pressure, anthropometry/body composition, food intake and metabolic biomarkers.

\section{Methods}

LORANS is an observational study consisting of two visits (before and after Ramadan) that was conducted to evaluate the impact of Ramadan fasting on health. Initially, we contacted six large mosques in London and invited them to support our study. Five large mosques 
medRxiv preprint doi: https://doi.org/10.1101/2021.07.14.21260518; this version posted July 16, 2021. The copyright holder for this preprint (which was not certified by peer review) is the author/funder, who has granted medRxiv a license to display the preprint in perpetuity.

It is made available under a CC-BY 4.0 International license .

including Almanaar Mosque (https://almanaar.org.uk/), Beitulfutuh Mosque (www.baitulfutuh.org), Madina Mosque (https://madina-masjid.org.uk/), Finsbury Park Mosque (http://www.finsburyparkmosque.org/), and West London Mosque (https://almuntadatrust.org/) agreed to collaborate with us (Fig. 1). We advertised the study via the mosques' social media channels (Facebook page, Twitter account and newsletters). The announcements offered the opportunity to participate in a study exploring the impact of Ramadan fasting on health.

Moreover, we spoke to the public in the mosques during daily and Friday prayers. We installed several posters and our research assistants distributed invitation flyers in the mosques. Those who were willing to participate were able to make an appointment for the first visit via the study website or a phone number. Also, we allowed individuals without appointments to walk in and take part in the study on the recruitment days. Each participant received the results of physical examinations and blood tests for the tests before and after Ramadan, which could indicate the impact of Ramadan fasting on their health.

\section{$\underline{\text { Inclusion and exclusion criteria }}$}

An individual had to be 18 years or older and planning to fast at least 20 days of Ramadan to participate in the study. We excluded pregnant women and individuals who were not able to attend the second visit after Ramadan.

Measurements and data were collected from every participant twice, before Ramadan (26 April - 30 April) and after Ramadan (10 June - 14 June) (Fig. 2). The examinations were done by three teams that rotated across the mosques. Each team consisted of a registered phlebotomist and two research assistants (male and female). The teams were trained in two sessions in advance of the study in a clinic similar to those at mosques to learn the protocols and harmonise the measurements and data collection. 
Clinics were set up from 1 to 5 days in various mosques depending on the expected number of participants. Each clinic was consisted of four stations as follows:

\section{First station}

Initially, participants were asked to read the participant information sheet and sign the informed consent form. Each participant was given a unique barcode. Then, using a tablet and a secure application, participants completed an online questionnaire. The questionnaire included questions on demographics, physical activity, sleep pattern, current health issues, medical history, smoking and alcohol consumption, mental health and fasting history (Appendix 1).

\section{Second station}

The research assistant measured the anthropometric measurements (by calculating the average of two measurements for each parameter) and body composition. Anthropometric measurements include height (using Leicester Height Measure), weight (Marsden digital weighing scale), waist and hip circumference (tape measure). A bioelectrical impedance analyser (Tanita BC-418) was used to measure body composition. Anthropometric measurements and body composition were not collected for participants with pacemakers or metal implants.

\section{$\underline{\text { Third station }}$}

The phlebotomist measured blood pressure (Omron 705-IT) three times, then collected a blood sample ( $2 \times 9 \mathrm{ml}$ EDTA, $2 \times 5 \mathrm{ml}$ serum separation tubes, $1 \times$ RNA stabiliser). In mosques, blood samples were kept in thermoporters ( $1-6$ hours) which were sent within one hour by a courier to the laboratory in Charing Cross Hospital (London, UK) for routine measurements. The remaining samples were aliquoted and stored in a long-term repository $\left(-80^{\circ} \mathrm{C}\right)$ 


\section{Fourth station}

At the end, participants were given a food diary to be completed for three days (two weekdays and a weekend day) before Ramadan and three days during Ramadan to observe their diet. The food diary booklet had usage instructions, including an example of food intake for one day completed to show how to describe food or their amount. There was a section dedicated for reporting the participant's vitamins/minerals or other food supplements.

The food diaries were collected during the second visit.

During the last ten days of Ramadan, we contacted participants using different methods (phone calls, letters and emails) to confirm their appointments after Ramadan and remind them to fill out their food diaries for three days during Ramadan.

After Ramadan, the second visit was done in the same way as the first one. Ethical approval was obtained from the Imperial College Research Ethics Committee (reference: 19IC5138, dated 17/4/2019).

\section{Food intake}

We used Nutritics (nutrition software) to analyse the food diaries (39).

\section{Metabolomics measurements}

A year later, aliquots of plasma were sent via an international courier (https://www.worldcourier.com/) to Nightingale laboratory in Finland for metabolic biomarker profiling (https://nightingalehealth.com/biomarkers).

\section{Results}

Before Ramadan, we collected data from 146 participants, of whom 85 attended the second visit. The group who did not complete the study $(n=61)$ had no daily smokers and was 
medRxiv preprint doi: https://doi.org/10.1101/2021.07.14.21260518; this version posted July 16, 2021. The copyright holder for this preprint

younger than the group who attended the two visits (appendix 2). Of the 85 participants who completed the study, 55 (47.1\%) were females. The mean age of the participants was $45.6 \pm 15.9$ years. Overall, $25.5 \%$ of the study population were obese ( $\geq 30 \mathrm{~kg} / \mathrm{m}^{2}$ ), $4.7 \%$ were smokers, $14 \%$ had diabetes (self-reported), $24 \%$ had hypertension (self-reported), and $5.2 \%$ had cardiovascular diseases. In addition, $81.2 \%$ had fasted the whole month (30 days), and the mean of fasted days during Ramadan was 28.6 days. Table 1 presents the baseline characteristics of the 85 participants who completed the study. We collected data on anthropometry and blood pressure in both visits for 85 participants (100\%), body composition from 84 (98.8\%), blood samples from 81 (95.3\%) and food diaries from 56 (65.9\%) participants. Figure 3 links types of data collected to locations (mosques).

After processing raw data of the food diaries, we acquired data on around 190 nutrients, including proteins, lipids, carbohydrates, fibre, vitamins, water and minerals. In addition, Nightingale laboratory applied metabolic biomarker profiling and provided us with data on 249 metabolites for each blood sample (Fig. 2).

\section{Discussion}

LORANS recruited a sample from various ethnic groups with different cultures. Collected data included lifestyle, food intake, blood pressure, anthropometry/body composition and metabolic biomarkers. Although the only incentive we offered was receiving personalised feedback on the impact of Ramadan fasting on participants health, people were willing to volunteer and participate. This study has shown that conducting large scale studies in under-studied populations is feasible. 
medRxiv preprint doi: https://doi.org/10.1101/2021.07.14.21260518; this version posted July 16, 2021. The copyright holder for this preprint (which was not certified by peer review) is the author/funder, who has granted medRxiv a license to display the preprint in perpetuity.

It is made available under a CC-BY 4.0 International license .

In LORANS, we managed to recruit a sample that is larger than most of the former Ramadan fasting studies. Recruiting individuals in such studies could be challenging, which explains the small samples in most previous studies. Conducting LORANS, we built experience in recruiting large samples with high follow up rates in future. We learned that engaging the mosque administration facilitates approaching and encouraging mosques attendees to participate in the study. Another factor is that all mosques receive a large number of people on Friday midday prayer (Zuhur) compared to other prayers across the weekdays. This massive gathering is an excellent opportunity to spread the word about the study. In addition, door to door advertising in Muslim-majority neighbourhoods would attract more participants. In LORANS, we had limited time to advertise the study since the ethical approval arrived less than two weeks before Ramadan. Many participants plan their holiday for the days after the fasting month. In many cases, they were not available for the particular day that we had the clinic in the mosque for the second visit. Having the clinic for several days in each mosque after Ramadan will increase the number of people who attend the follow up visit.

In summary, LORANS has recruited a multicultural community-based sample from a city with various ethnic groups. The recruited sample was balanced in terms of age groups and gender. Furthermore, LORANS has collected a comprehensive set of data on lifestyle and health which enables us to analyse the data considering all important factors. LORANS further shows that conducting large studies on the health effects of Ramadan fasting is feasible. Engaging the mosque administrations, long-term and extensive advertisement for the study and sufficient time for clinics after Ramadan are essential for recruiting large samples and high rates of follow up. 


\section{Acknowledgements}

We would like to thank all participants in LORANS. We also thank Ahlam Khamliche, Kimberley Bennett and Jordan Jenkins for their assistance in data collection and management. We thank Aida Abdelwahed, Saredo Said, Rima Mustafa, Hamad Al Jafar, Faisal Al-Ghamdi, Sharmin Akbar, Sadia Zaman, Rahma Hassan, Amna Ahmed, Shifa Bangi, Mahnoor Ahmed, Karim Belhaj, Manal Al Jafar and Yi ZHAO who volunteered to advertise the study and collect data.

\section{Funding sources}

This project was partially funded by the Saudi Embassy in London. 


\section{Reference}

1. Azizi F. Islamic fasting and health. Ann Nutr Metab. 2010;56(4):273-82.

2. Abuznaid S. Islam and management: What can be learned? Thunderbird International Business Review. 2006;48(1):125-39.

3. Norouzy A, Salehi M, Philippou E, Arabi H, Shiva F, Mehrnoosh S, et al. Effect of fasting in Ramadan on body composition and nutritional intake: a prospective study. J Hum Nutr Diet. 2013;26 Suppl 1:97-104.

4. $\quad$ Kiyani MM, Memon AR, Amjad MI, Ameer MR, Sadiq M, Mahmood T. Study of Human Biochemical Parameters During and After Ramadan. J Relig Health. 2017;56(1):55-62.

5. Ali Z, Abizari AR. Ramadan fasting alters food patterns, dietary diversity and body weight among Ghanaian adolescents. Nutr J. 2018;17(1):75.

6. Nachvak SM, Pasdar Y, Pirsaheb S, Darbandi M, Niazi P, Mostafai R, et al. Effects of Ramadan on food intake, glucose homeostasis, lipid profiles and body composition composition. European Journal of Clinical Nutrition. 2018:1-7.

7. Ziaee V, Razaei M, Ahmadinejad Z, Shaikh H, Yousefi R, Yarmohammadi L, et al. The changes of metabolic profile and weight during Ramadan fasting. Singapore Med J. 2006;47(5):409-14.

8. Al-Numair K. Body Weight and Some Biochemical Changes Associated with Ramadan Fasting in Healthy Saudi Men. Journal of Medical Sciences. 2006;6(1):112-6.

9. sijavandi MSA, Shahsavan F, Askarizadeh F, Nematy M, Heravian J, Mahmodi Z, et al. Effect of Ramadan Fasting on Blood Pressure and Lipid Profiles. Journal of Fasting and Health.

2015;3(3):126 - 31.

10. Amiri F, Nezhad M, Alinezhad-namaghi M, Jarahi L, Nematy M, Norouzy A. Effects of Ramadan fasting on inflammatory biomarkers and body composition in healthy subjects. 2016;4(4):136-9.

11. Akkoca M, Metin ZE, Topaloglu O, Tokgoz S, Cihan G, San I. An evaluation of the effects of Ramadan fasting on anthropometric, metabolic and endocrine parameters. Progress in Nutrition. 2018;20(3):503-9.

12. Ongsara S, Boonpol S, Prompalad N, Jeenduang N. The Effect of Ramadan Fasting on Biochemical Parameters in Healthy Thai Subjects. J Clin Diagn Res. 2017;11(9):BC14-BC8.

13. Yucel A, Degirmenci B, Acar M, Albayrak R, Haktanir A. The effect of fasting month of Ramadan on the abdominal fat distribution: assessment by computed tomography. Tohoku J Exp Med. 2004;204(3):179-87.

14. Ghania T, Boumediene Meghit K, Mustapha D, Sarah S, Ghizlane B. Effect of Ramadan Fasting on Serum Glucose and Lipid Profile Among Algerian Type 2 Diabetes Patients. Romanian Journal of Diabetes Nutrition and Metabolic Diseases. 2015;22(4):385-92.

15. Patel P, Mirakhur A, El-Magd KMA, El-Matty ANA, Al-Ghafri D. Type 2 Diabetes and its Characteristics during Ramadan in Dhahira Region, Oman. Oman Med J. 2007;22(3):16-23.

16. Sulu B, Öztürk B, Güven A, Kilic K. The Effect of Long-Term Controlled Fasting (The Ramadan Model) on Body Mass Index, Blood Biochemistry and Oxidative Stress Factors. Turkiye Klinikleri Tip Bilimleri Dergisi. 2010;30:855-63.

17. Toony LFE, Hamad DA, Omar OM. Outcome of focused pre-Ramadan education on metabolic and glycaemic parameters in patients with type 2 diabetes mellitus. Diabetes Metab Syndr. 2018;12(5):761-7.

18. Bencharif M, Chaima B, Amal F, Youcef B. Effect of Pre-Ramadan Education on Dietary Intake and Anthropometry-Comparison Between Two Groups of Diabetic Patients. Romanian Journal of Diabetes Nutrition and Metabolic Diseases. 2017;24(4):295-307.

19. Alzoughool F, Hourani HM, Atoum M, Abdelgader R, Alanagreh L. Irisin, leptin and adiponectin levels are reduced significantly during fasting. Mediterranean Journal of Nutrition and Metabolism. 2019;12:389-96.

20. Finch GM, Day JE, Razak, Welch DA, Rogers PJ. Appetite changes under free-living conditions during Ramadan fasting. Appetite. 1998;31(2):159-70. 
medRxiv preprint doi: https://doi.org/10.1101/2021.07.14.21260518; this version posted July 16, 2021. The copyright holder for this preprint

(which was not certified by peer review) is the author/funder, who has granted medRxiv a license to display the preprint in perpetuity.

It is made available under a CC-BY 4.0 International license .

21. Khan N, Rasheed A, Ahmed H, Aslam F, Kanwal F. Effect of Ramadan fasting on glucose level, lipid profile, $\mathrm{HbA1C}$ and uric acid among medical students in Karachi, Pakistan. E Mediterr Health J. 2017;23(4):274-9.

22. Dewanti L, Watanabe C, Sulistiawati, Ohtsuka R. Unexpected changes in blood pressure and hematological parameters among fasting and nonfasting workers during Ramadan in Indonesia. Eur J Clin Nutr. 2006;60(7):877-81.

23. Al-Shafei Al. Ramadan fasting ameliorates oxidative stress and improves glycemic control and lipid profile in diabetic patients. Eur J Nutr. 2014;53(7):1475-81.

24. Faris MA, Kacimi S, Al-Kurd RA, Fararjeh MA, Bustanji YK, Mohammad MK, et al. Intermittent fasting during Ramadan attenuates proinflammatory cytokines and immune cells in healthy subjects. Nutr Res. 2012;32(12):947-55.

25. Dasgupta A, Garg S, Jr., Pal B, Maharana SP, Bandhopadhayay L, Mallick N, Jr. Is ramadan fasting cardio-protective? A study in a village of West Bengal. Indian Journal of Community Health. 2017;29(2):203-8.

26. Salahuddin M, Sayed Ashfak AH, Syed SR, Badaam KM. Effect of ramadan fasting on body weight, blood pressure and biochemical parameters in middle aged hypertensive subjects: An observational trial. Journal of Clinical and Diagnostic Research. 2014;8(3):16-8.

27. Sezen Y, Altiparmak IH, Erkus ME, Kocarslan A, Kaya Z, Gunebakmaz O, et al. Effects of Ramadan fasting on body composition and arterial stiffness. J Pak Med Assoc. 2016;66(12):1522-7.

28. Gupta M, Khajuria V, Akhter P. Effects of ramadan fasting on cardiovascular and biochemical parameters. Indian Journal of Community Health. 2013;25(4):460-4.

29. Sijavandi M, Shahsavan F, Askarizadeh F, Nematy M, Heravian J, Mahmodi Z, et al. Effect of Ramadan Fasting on Blood Pressure and Lipid Profiles. 2015;3(3):126-31.

30. Sahin SB, Ayaz T, Ozyurt N, Ilkkilic K, Kirvar A, Sezgin H. The impact of fasting during ramadan on the glycemic control of patients with type 2 diabetes mellitus. Experimental and Clinical Endocrinology and Diabetes. 2013;121(9):531-4.

31. Larijani B, Zahedi F, Sanjari M, Amini M, Jalili R, Adibi H, et al. The effect of Ramadan fasting on fasting serum glucose in healthy adults. Med J Malaysia. 2003;58(5):678-80.

32. Qujeq D, Bijani K, kalavi K, mohiti J, Aliakbarpour H. Effects of Ramadan fasting on serum low-density and high-density lipoprotein-cholesterol concentrations. Ann Saudi Med. 2002;22(56):297-9.

33. Khan N, Rasheed A, Ahmed H, Aslam F, Kanwal F. Effect of Ramadan fasting on glucose level, lipid profile, $\mathrm{HbA} 1 \mathrm{c}$ and uric acid among medical students in Karachi, Pakistan. East Mediterr Health J. 2017;23(4):274-9.

34. Hackshaw A. Small studies: strengths and limitations. Eur Respir J. 2008;32(5):1141-3.

35. Banerjee A, Chaudhury S. Statistics without tears: Populations and samples

Ind Psychiatry J. 2010;19(1):60-5.

36. Barrow M. Time Zone 2013 [Available from:

http://www.primaryhomeworkhelp.co.uk/time/meridian.htm.

37. Consultants GSM. Ramadan and Change in Working Hours During Ramadan 2017 [Available from: https://www.linkedin.com/pulse/ramadan-change-working-hours-during-managementconsultants.

38. Allen L, Williams J, Townsend N, Mikkelsen B, Roberts N, Foster C, et al. Socioeconomic status and non-communicable disease behavioural risk factors in low-income and lower-middleincome countries: a systematic review. Lancet Glob Health. 2017;5(3):e277-e89.

39. Nutritics, Research Edition, v5.09, Dublin, Nutritics, 2019. 
medRxiv preprint doi: https://doi.org/10.1101/2021.07.14.21260518; this version posted July 16, 2021. The copyright holder for this preprint (which was not certified by peer review) is the author/funder, who has granted medRxiv a license to display the preprint in perpetuity.

It is made available under a CC-BY 4.0 International license .

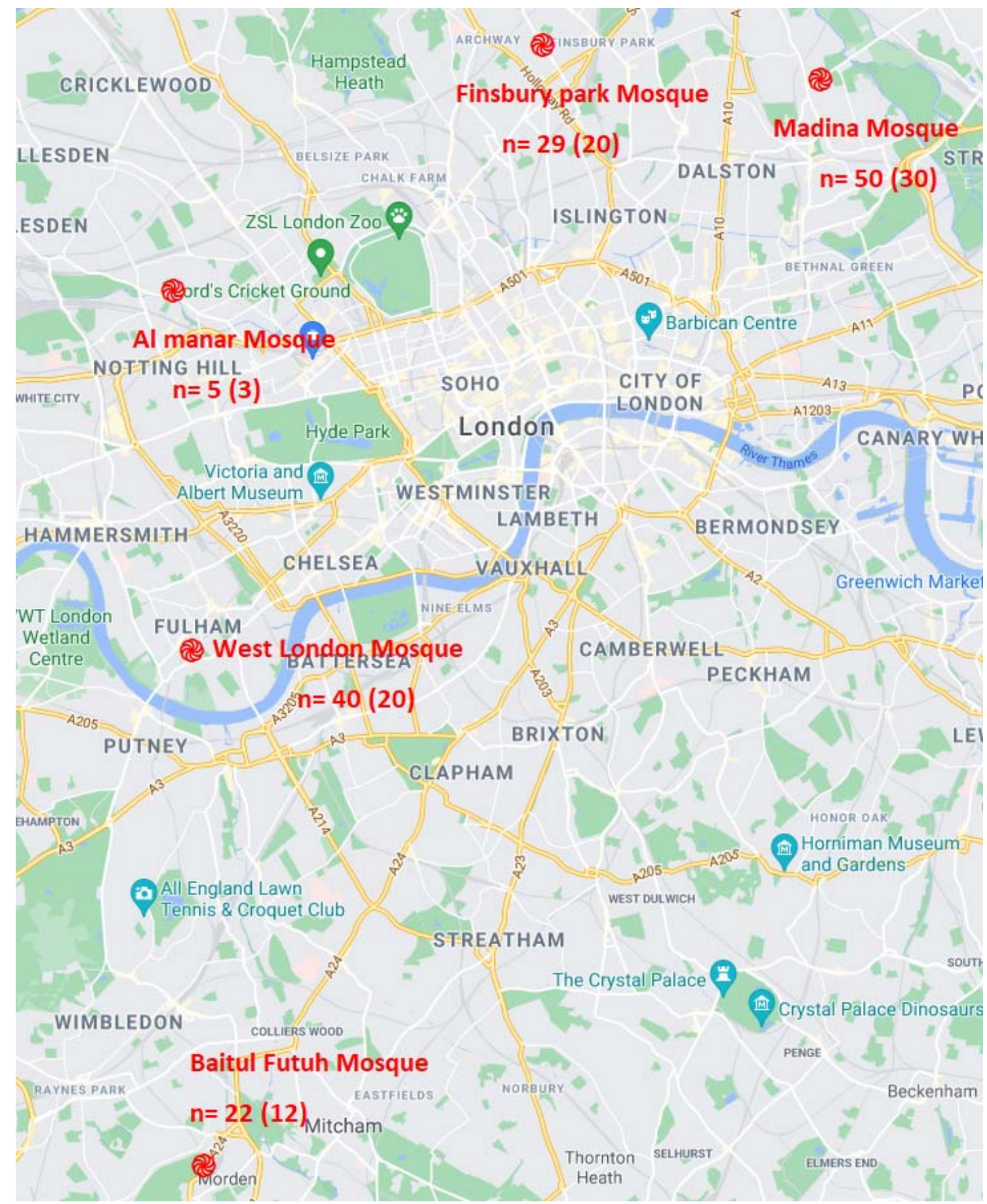

Figure1: Mosques locations and numbers as baseline (follow up) by mosques. 


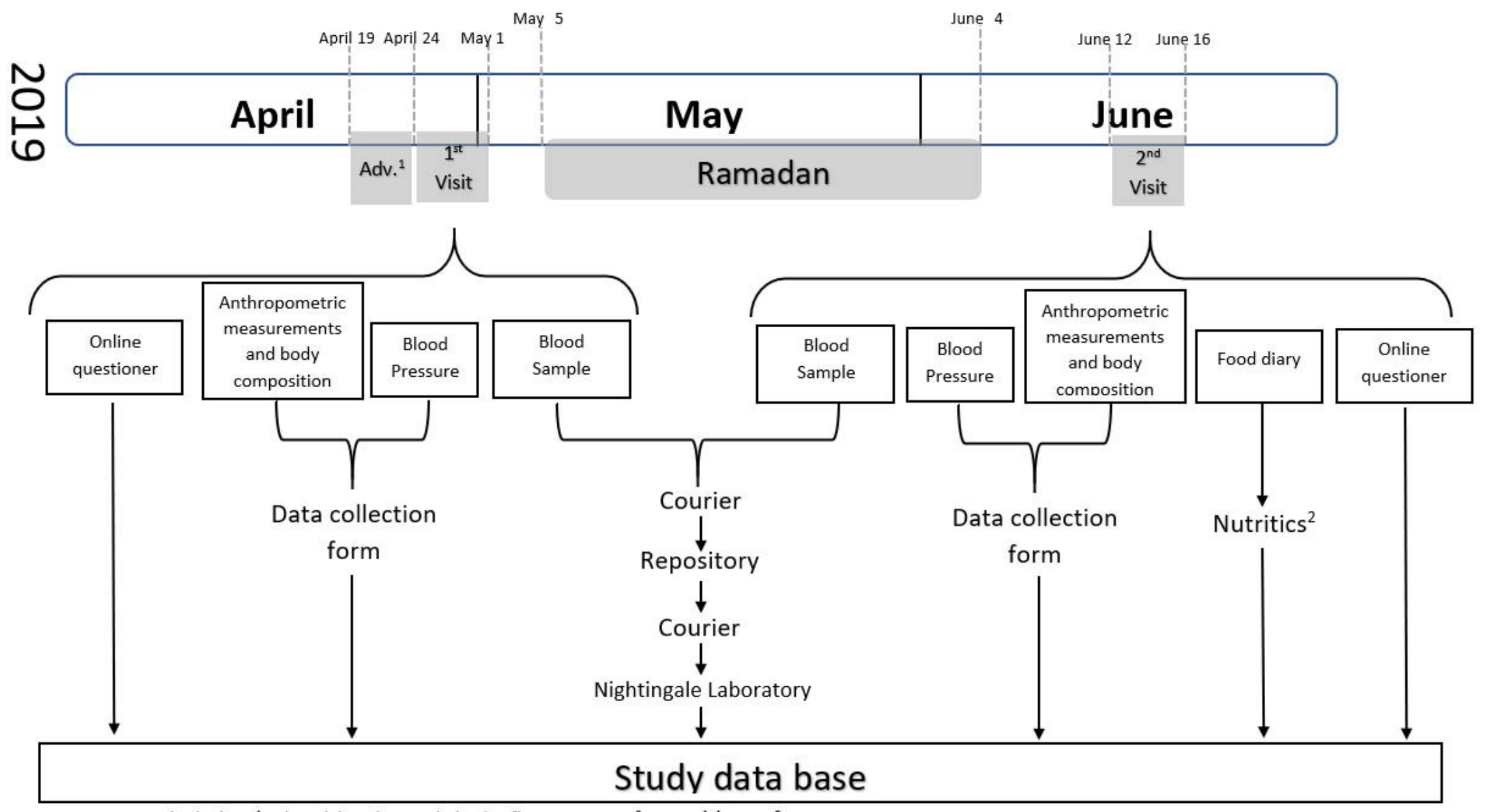

Figure 2: Study design. ${ }^{1}$ advertising the study in the five mosques. ${ }^{2}$ a nutrition software. 
medRxiv preprint doi: https://doi.org/10.1101/2021.07.14.21260518; this version posted July 16, 2021. The copyright holder for this preprint (which was not certified by peer review) is the author/funder, who has granted medRxiv a license to display the preprint in perpetuity.

It is made available under a CC-BY 4.0 International license .

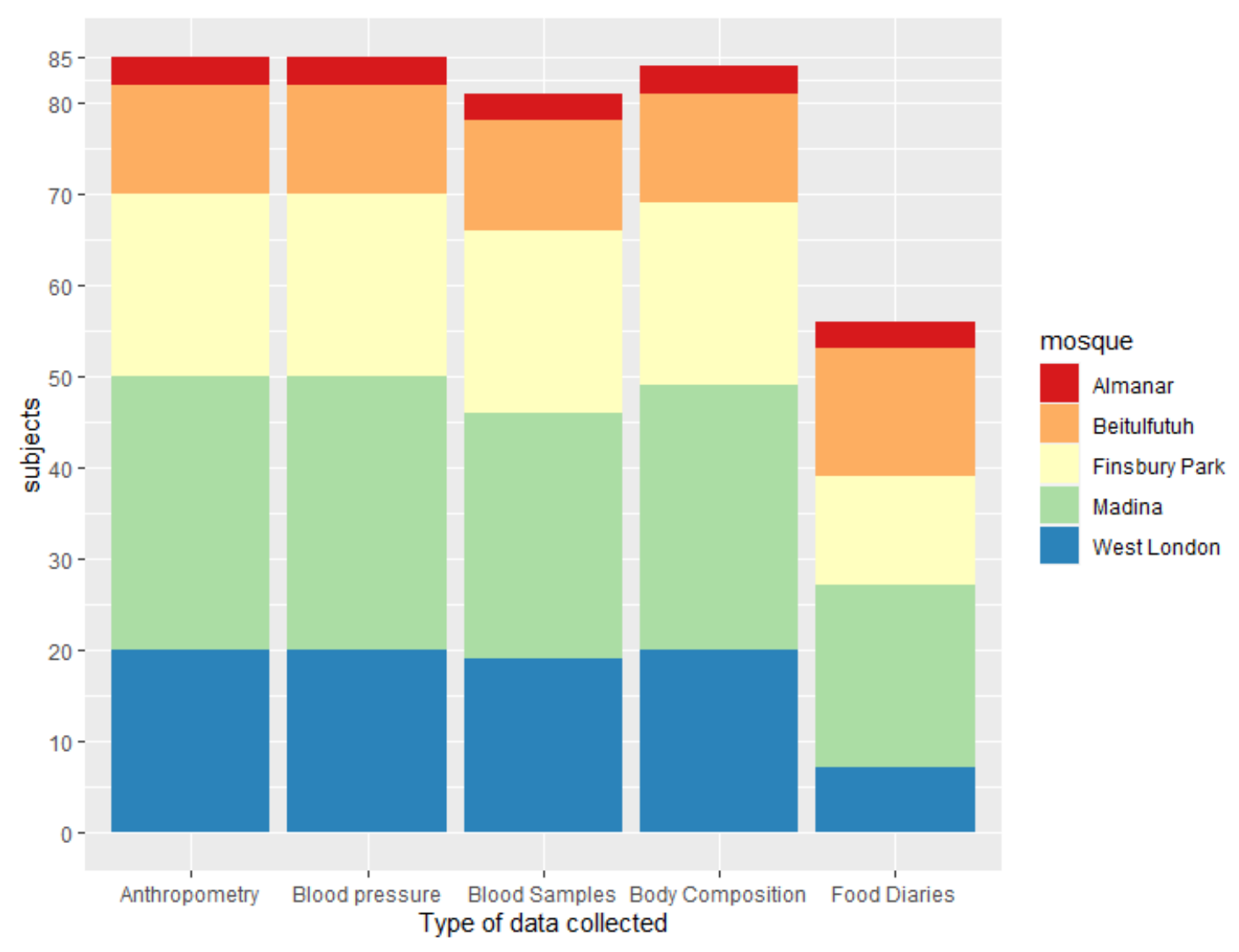

Figure3: types of collected data by locations (mosques). 
medRxiv preprint doi: https://doi.org/10.1101/2021.07.14.21260518; this version posted July 16, 2021. The copyright holder for this preprint (which was not certified by peer review) is the author/funder, who has granted medRxiv a license to display the preprint in perpetuity.

It is made available under a CC-BY 4.0 International license .

Table1: baseline characteristics of the 85 participants who completed the study by gender.

\begin{tabular}{|c|c|c|c|}
\hline & $\begin{array}{c}\text { Men } \\
(n=45)\end{array}$ & $\begin{array}{l}\text { Women } \\
(n=40)\end{array}$ & $\begin{array}{c}\text { Total } \\
(n=85)\end{array}$ \\
\hline $\mathrm{N}(\%)$ & 52.9 & 47.1 & 100 \\
\hline Age (mean (SD)) & $46.5(16.3)$ & $44.6(15.4)$ & $45.6(15.9)$ \\
\hline $18-40$ & 33.3 & 30 & 31.8 \\
\hline $40-60$ & 42.2 & 57.5 & 49.4 \\
\hline $60-80$ & 22.2 & 12.5 & 17.6 \\
\hline$>80$ & 2.2 & 0 & 1.2 \\
\hline Fasted the whole month ( 30 days) & 95.5 & 65 & 81.2 \\
\hline \multicolumn{4}{|l|}{ Ethnicity } \\
\hline Arab & 19 & 13.5 & 16.5 \\
\hline Bangladeshi & 9.5 & 8.1 & 8.9 \\
\hline Indian & 23.8 & 29.7 & 26.6 \\
\hline Pakistani & 4.3 & 18.9 & 16.5 \\
\hline Somali & 19 & 13.5 & 16.5 \\
\hline Other & 14.3 & 16.2 & 15.2 \\
\hline \multicolumn{4}{|l|}{ BMI } \\
\hline$<25 \mathrm{~kg} / \mathrm{m}^{2}$ & 37.8 & 25 & 31.8 \\
\hline$\geq 25 \mathrm{~kg} / \mathrm{m}^{2} \&<30 \mathrm{~kg} / \mathrm{m}^{2}$ & 52.2 & 35 & 44.1 \\
\hline$\geq 30 \mathrm{~kg} / \mathrm{m}^{2} \&<35 \mathrm{~kg} / \mathrm{m}^{2}$ & 7.7 & 26.2 & 16.5 \\
\hline$\geq 35 \mathrm{~kg} / \mathrm{m}^{2} \&<40 \mathrm{~kg} / \mathrm{m}^{2}$ & 2.2 & 11.2 & 6.5 \\
\hline$\geq 40 \mathrm{~kg} / \mathrm{m}^{2}$ & 1.2 & 0 & 2.5 \\
\hline \multicolumn{4}{|l|}{ Marital status } \\
\hline Married/living with a partner & 69 & 78.4 & 73.4 \\
\hline Single & 28.6 & 16.2 & 22.8 \\
\hline Divorced/separated & 2.4 & 5.4 & 3.8 \\
\hline \multicolumn{4}{|l|}{ Chronic diseases } \\
\hline Diabetes & 19 & 8.1 & 14 \\
\hline Hypertension & 26.2 & 21.6 & 24 \\
\hline Cardiovascular diseases & 7.3 & 2.8 & 5.2 \\
\hline \multicolumn{4}{|l|}{ Education } \\
\hline No formal qualification & 7.1 & 18.9 & 12.7 \\
\hline Secondary school or equivalent & 21.4 & 29.7 & 25.3 \\
\hline Higher education: College/HNC/HND & 19 & 24.3 & 21.5 \\
\hline Vocational qualification & 2.3 & 0 & 1.3 \\
\hline Bachelor's degree & 28.5 & 24.3 & 26.6 \\
\hline Postgraduate degree & 21.4 & 2.7 & 12.7 \\
\hline \multicolumn{4}{|l|}{ Smoking } \\
\hline Never & 57.7 & 100 & 77.6 \\
\hline Stopped & 26.6 & 0 & 14.1 \\
\hline Occasionally & 6.6 & 0 & 3.5 \\
\hline Yes, most or all days & 8.8 & 0 & 4.7 \\
\hline
\end{tabular}

Percentages are presented for all variables except for age (mean (SD)). 